\title{
Optimization of irrigation water use to increase the benefit of agricultural products
}

\author{
Edy Anto Soentoro ${ }^{1}$, Erlangga Perwira $^{2}$, Yadi Suryadi $^{1}$, and Winskayati $^{3}$ \\ ${ }^{1}$ Water Resources Engineering Research Group, FCEE, Institut Teknologi Bandung, Indonesia. \\ ${ }^{2}$ Master Program in Water Resources Management, FCEE, Institut Teknologi Bandung, Indonesia. \\ ${ }^{3}$ Citarum River Basin Authority, Ministry of Public Works and Housing, Indonesia.
}

\begin{abstract}
Shortage of irrigation water supply in dry season prevents many farmers from growing their crops, and the annual benefit from agricultural products will decrease as much as the area of irrigation fields which have lack of water. The objective of this study is to determine the maximum benefit from agricultural products based on water availability, by determining the appropriate cropping pattern and maximum planting areas through linear programming. The case-study location is at Leuwi Kuya Irrigation Region. Planting schedule is selected based on minimum water shortage from simulation of 6 alternative planting schedules. Then, the best pattern of cropping (planting method and the total area) is determined using linear programming. Optimization is carried out in 3 scenarios with various planting methods (conventional and SRI), minimum irrigation water demand (class-area system), and schedule for beginning of the 3-growing seasons annually. Result of this study is the optimal area of the irrigated region that can be planted based on the water availability. The maximum benefit is 89 billion rupiahs, using SRI planting method and distribution of three groups of irrigation fields in water supply schedule.
\end{abstract}

Key words: Optimization, linear programming, irrigation, planting area.

\section{Introduction}

Shortage of irrigation water supply in dry season has caused some areas of paddy field to have lack of water and eventually causing many farmers to lose their crops. The annual benefit from agricultural product of farmer decreases as much as the area of irrigation fields which do not get enough water. Decades ago when the Irrigation Region ("Daerah Irigasi") had been built by the Government, the river flow discharge through a weir was enough to supply irrigation water for wet and dry seasons. Due to land-use change in the upstream of the watershed over decades, river flows supplying irrigation water became unstable, causing flood in wet season and small discharge in dry season. Thus, there are not enough irrigation water to supply irrigation area in the region that has been built. So, the government money for building infrastructures in the Irrigation Region is "useless" during dry season, and some of the farmers cannot plant their crops. One effort to overcome the problem above is by finding the optimal cropping pattern and planting area based on water availability.

* Corresponding author: edyas209@gmail.com 
The objective of this study is to optimize irrigation water use to increase the benefit of agricultural products using best cropping pattern and linear programing. Result of the study will determine the area of irrigation region which can get enough irrigation water, the crop type, and how much benefits that can be obtained from agricultural products for each growing season, based on water availability.

The study location is Leuwi Kuya Irrigation Region (Daerah Irigasi Leuwi Kuya), West Java Province covering 2,535 ha of paddy fields. Infrastructure of Leuwi Kuya Irrigation Region is in good condition, there is no sedimentation problem in canals that obstructs the water distribution process. Data used in this study are regulations related to pattern and planting system, rainfall and flow discharges, irrigation area, agricultural production, and commodity prices data.

The existing PS (planting schedule) in Leuwi Kuya Irrigation Region has water shortage in dry season, many farmers fail to grow their crops, as well as reducing the benefit of agricultural products. During one-year period, there are 3 times of growing season (GS) for two or three crop types (paddy-paddy-"palawija") in the Irrigation Region. The planting schedule (PS) is the beginning of the first growing season of a one-year period, and it is determined based on the balance between water requirement and water availability. Simulation procedure of water balance in every half month (e.g., October-1 or the first half of October) is applied to select the best time of planting schedule (PS).

\section{Methodology}

There are three stages of analysis in this study to optimize the irrigation water use to increase the benefit of agricultural products.

1. Determine the best planting schedule (PS) of 6 alternatives PSs based on the minimum water requirement through simulation procedure.

2. Apply Linear Programing [1,3] on the best PS, and maximize the area of irrigation field that gets enough water from 3 scenarios of Pattern and Cropping Order (PCO), and,

3. Compare each scenario in terms of cropping intensity and the resulting benefits. Detailed of stage analysis are as follows:

\subsection{Stage 1: Determine the best Planting Schedule (PS)}

At this stage, the best planting schedule (PS) is chosen from 6 alternatives of PSs, beginning from October-1 (first half of October) to December-2 (second half of December). The selection is through simulations that are based on the minimum water shortage of each alternative. The planting methods that applied in the study are conventional and SRI methods. Optimization by Linear Programing is carried out based on 3 scenarios as follows,

- Scenario 1: Conventional method for growing the crop is applied on the best planting schedule (PS) from simulation of 6 PS alternatives.

- Scenario 2: SRI method [4] for growing the crop is applied on the best PS.

- Scenario 3: SRI method is applied on one PS that is not the best, to know the effect of method change on pattern determination and planting system.

There are three growing season (GS) in one-year planting schedule. In the first and second GS (GS-1 and GS-2), the entire irrigated field is planted with paddy, while in the third GS (GS-3) it is planted with "palawija" such as corn or soybean. Period of GS-1, GS2 , and GS-3 are 3.5, 3.5, and 3 months respectively. In order to reduce total required water supply at intake, a best practice of group system ("system golongan") is used. The irrigation region is divided into 3 groups of irrigation fields in which each planting schedule is different a half month to each other. The division is based on the scheme of the canal and box structure to regulate water flows. 


\subsection{Stage 2: Maximize the planting area based on water availability.}

At this stage, optimization is carried out by linear programing to determine maximum area that can get enough water based on water availability for each half-month during a one-year period. The calculation is starting from the beginning of planting schedule, and is done for every half-month period. A sample of the linear programming optimization model is to determine the optimum area that cat get enough water $\left(A R_{\mathrm{j}, 1}, A R_{\mathrm{j}, 2}\right.$, and $\left.A R_{\mathrm{j}, 3}\right)$ for period 3 $(\mathrm{j}=3$, November-2) with group of irrigation field: $\mathrm{k}=1,2$, and 3 , is as below:

$\operatorname{Max} Z=R p . B *(A R j, 1+A R j, 2+A R j, 3)$

Subject to:

$V R E Q 1 * A R j, 1+V R E Q 2 * A R j, 2+V R E Q 3 * A R j, 3 \leq V A V L j$

$A R j, 1+A R j, 2+A R j, 3 \leq A R$ total

$A R j, 1=A R j-1,1$

$A R j, 2=A R j-1,2$

$A R j, 1 \geq 0 ; A R j, 2 \geq 0 ; A R j, 3 \geq 0$

Rp. $B \quad$ : net benefit for paddy crop (Rp. million/ ha)

$A R j, k$ : total area (in (Ha) of group $\mathrm{k}$ irrigation field, period $\mathrm{j}$ which can get enough water $V R E Q j$ : volume of water requirement at intake in the $\mathrm{j}^{\text {th }}$ half month $\left(\mathrm{m}^{3} / \mathrm{s}\right)$ for group area $\mathrm{j}$ $V A V L j$ : volume of water available at intake in the $\mathrm{j}^{\text {th }}$ half month $\left(\mathrm{m}^{3} / \mathrm{s}\right)$

\subsection{Stage 3: Compare the optimization results.}

This third stage is to continue what has been obtained from the optimization process in the second stage, by choosing scenarios that provide the highest value of irrigation benefits in terms of benefits which are generated.

\section{Result of study and discussion}

Simulation method is used to determine the optimal planting schedule (PS) in Leuwi Kuya Irrigation Region from 6 alternatives of proposed planting schedules, while the existing planting schedule (PS) is the PS alternative-1. The optimal PS is evaluated based on the water required, and availability of irrigation water. After simulation by shifting per half-month from the beginning of planting schedule, the most optimal planting schedule is PS alternative-2, which has the smallest required discharge or volume of water during the year.

\subsection{Scenario 1}

In scenario 1, the conventional planting method is applied on the best alternative of planting schedule (PS), it is the PS -2 (starting at the $2^{\text {nd }}$ half month of October), with the smallest water shortage. Results obtained from optimization is shown in table and picture and below:

Table 1. Actual planting areas, Planting coverage and the Benefits of Scenario -1

\begin{tabular}{|c|c|c|c|c|c|c|c|c|}
\hline $\begin{array}{c}\text { Growing } \\
\text { Season } \\
\text { (GS) }\end{array}$ & $\begin{array}{l}\text { Group-1 } \\
\text { irrigation } \\
\text { field }\end{array}$ & $\begin{array}{l}\text { Group-2 } \\
\text { irrigation } \\
\text { field }\end{array}$ & $\begin{array}{l}\text { Group-3 } \\
\text { irrigation } \\
\quad \text { field }\end{array}$ & $\begin{array}{l}\text { Group-4 } \\
\text { irrigation } \\
\text { field }\end{array}$ & $\begin{array}{c}\text { Potential } \\
\text { planting } \\
\text { area }\end{array}$ & $\begin{array}{c}\text { Actual } \\
\text { planting } \\
\text { area }\end{array}$ & $\begin{array}{l}\text { Planting } \\
\text { coverage }\end{array}$ & Benefit \\
\hline & (ha) & (ha) & (ha) & (ha) & (ha) & (ha) & $(\%)$ & Billion Rp. \\
\hline GS -1 & 293 & 1149 & 362 & 731 & 2535 & 2535 & 100 & 27.046 \\
\hline GS -2 & 293 & 1149 & 362 & 731 & 2535 & 2535 & 100 & 27.046 \\
\hline GS -3 & 293 & 16 & 0 & 0 & 2535 & 309 & 12 & 4.536 \\
\hline \multicolumn{5}{|c|}{ Total in 1 year } & 7604 & 5378 & 212 & 58.628 \\
\hline
\end{tabular}

Source: Optimization result 

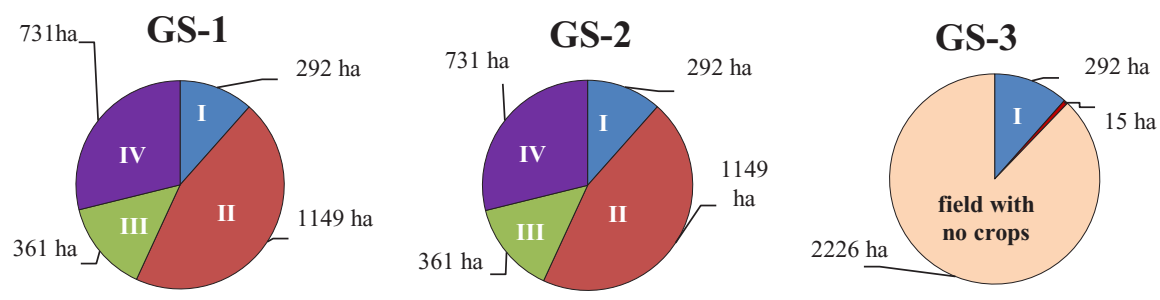

Fig. 1. Planting Area for each Group on Scenario-1 based on Water Availability

\subsection{Scenario 2}

In scenario 2 , it is attempted to increase the income of farmers through rice planting by System of Rice Intensification (SRI) method, which is more profitable than conventional methods. Based on the results of a study that has been conducted by the Research and Development Agency of the Ministry of Public Works [5], SRI method can reduce water demand drastically depending on the location where the SRI method is applied. Nevertheless, based on the calculation results, there is still a period of water shortage in GS-1, so optimization must be done. The SRI method of paddy crop is applied in GS-1 and GS-2, while in GS-3 it is soybean crop. The optimized cultivation pattern is PS alternative-2, which in scenario 1 has been optimized but with different cultivation methods. From the optimization process, the obtained results are as in table and picture below:

Table 2. Actual planting areas, Planting coverage and the Benefits of Scenario -2

\begin{tabular}{|c|c|c|c|c|c|c|}
\hline $\begin{array}{c}\text { Growing } \\
\text { Season } \\
\text { (GS) }\end{array}$ & $\begin{array}{c}\text { Group-1 } \\
\text { irrigation } \\
\text { field }\end{array}$ & $\begin{array}{l}\text { Group-2 } \\
\text { irrigation } \\
\text { field }\end{array}$ & $\begin{array}{c}\text { Potential } \\
\text { planting } \\
\text { area }\end{array}$ & $\begin{array}{c}\text { Actual } \\
\text { planting } \\
\text { area }\end{array}$ & $\begin{array}{l}\text { Planting } \\
\text { coverage }\end{array}$ & Benefit \\
\hline & (ha) & (ha) & (ha) & (ha) & $(\%)$ & Billion Rp. \\
\hline GS -1 & 43 & 2104 & 2535 & 2535 & 100 & 40.987 \\
\hline GS -2 & 43 & 2104 & 253 & 2535 & 100 & 40.987 \\
\hline GS -3 & 309 & 0 & 2535 & 309 & 12 & 4.536 \\
\hline \multicolumn{3}{|c|}{ Total in 1 year } & 7604 & 5378 & 212 & 86.510 \\
\hline
\end{tabular}

Source: Optimization result
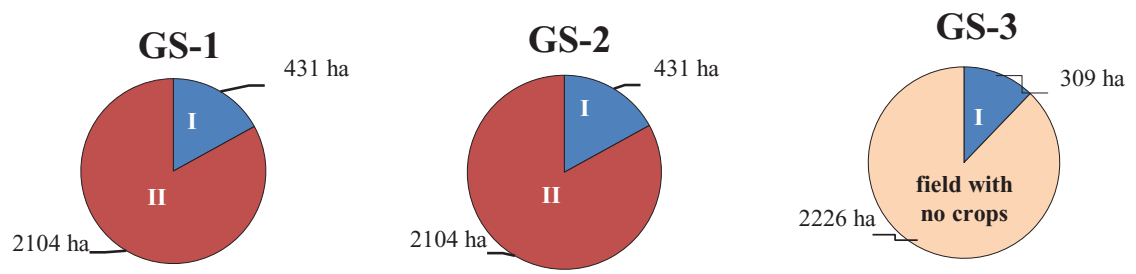

Fig. 2. Planting Area for each Group on Scenario-2 based on Water Availability.

It can be concluded from the above results that comparing with conventional methods, SRI method with the same planting schedule (PS-2: October-2) can give benefits by almost two times, although there is no increase in the planting coverage. In addition, implementation of SRI method can reduce the number of irrigated water group, from 4 group to become 2 groups only, thus making water division easier. 


\subsection{Scenario 3}

The scenario 3 is almost the same with scenario 2, in effort to increase farmer's profit through planting paddy with System of Rice Intensification (SRI) method. The difference from scenario 2 are the planting schedule and the number of group irrigated field. Scenario -3 used the PS-1 instead of the PS-2, and the irrigated region is divided into 3 groups of irrigated fields. The selected PS-1 (the existing condition) in scenario 3 is to furtherly increase the benefits that can be obtained by farmers through the water availability for GS-3 of PS-1 which is more than that of PS-2 on Scenario-2. The choice of 3 groups of irrigated fields is to minimize the total water requirement from the intake gate. Here is the recapitulation of optimization results in scenario 3 .

Table 3. Actual planting areas, Planting coverage and the Benefits of Scenario -3

\begin{tabular}{|c|c|c|c|c|c|c|c|}
\hline $\begin{array}{c}\text { Growing } \\
\text { Season } \\
\text { (GS) }\end{array}$ & $\begin{array}{c}\text { Group-1 } \\
\text { irrigation } \\
\text { field }\end{array}$ & $\begin{array}{c}\text { Group-2 } \\
\text { irrigation } \\
\text { field }\end{array}$ & $\begin{array}{c}\text { Group-3 } \\
\text { irrigation } \\
\text { field }\end{array}$ & $\begin{array}{c}\text { Potential } \\
\text { planting } \\
\text { area }\end{array}$ & $\begin{array}{c}\text { Actual } \\
\text { planting } \\
\text { area }\end{array}$ & $\begin{array}{c}\text { Planting } \\
\text { coverage }\end{array}$ & Benefit \\
\hline & (ha) & (ha) & (ha) & (ha) & (ha) & $(\%)$ & Billion Rp. \\
\hline GS -1 & 144 & 286 & 2104 & 2535 & 2535 & 100 & 40.987 \\
\hline GS -2 & 144 & 286 & 2104 & 2535 & 2535 & 100 & 40.987 \\
\hline GS -3 & 144 & 286 & 82 & 2535 & 512 & 20 & 7.527 \\
\hline \multicolumn{3}{|c|}{ Total in 1 year } & 7604 & 5582 & 220 & 89.501 \\
\hline
\end{tabular}

Source: Optimization result
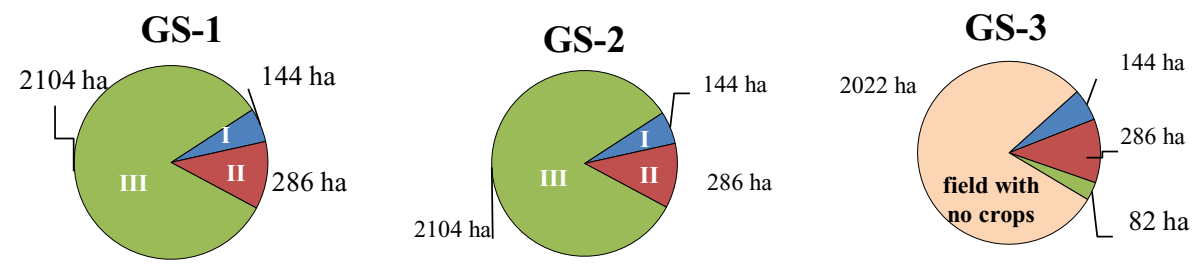

Fig. 3. Planting Area for each Group on Scenario-3 based on Water Availability

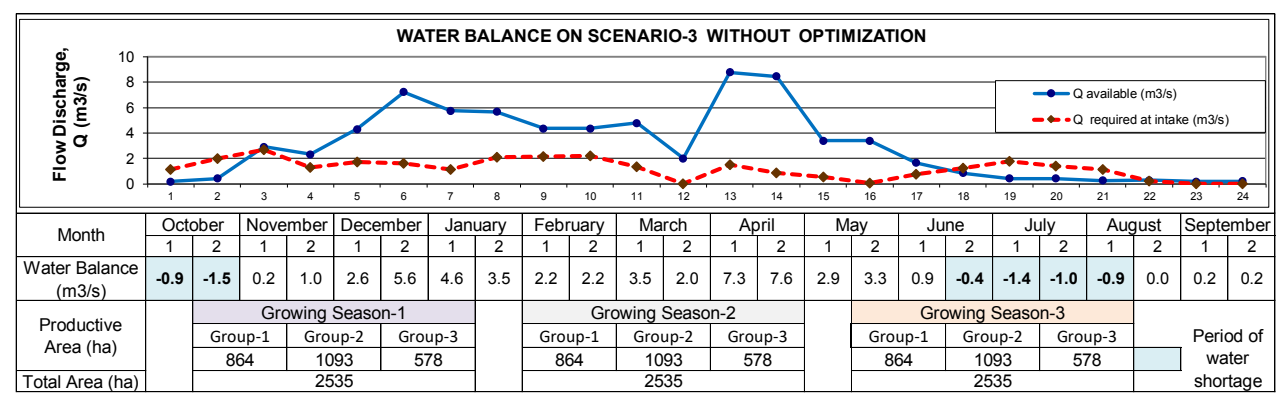

Source: Optimization result

Fig. 4. Water Balance on Scenario 3 without Optimization

Results of this study showed that there is a difference in the number of group division and the maximum planting coverage in this 3rd scenario with the situation in scenario 2 above. With the beginning of planting schedule which is back to October 1 as the existing conditions, and SRI method on growing season (GS) -1 and 2, the planting index for paddy crop remains $200 \%$ for GS-1 and GS-2. Planted with soybean crops in GS-3, there was an increase of actual planting area (productive area) from 308.65 ha to 512,72 ha, due to the 
availability of water. The planting coverage increased $8 \%$ and the benefit increased up to 3 billion rupiah per year.

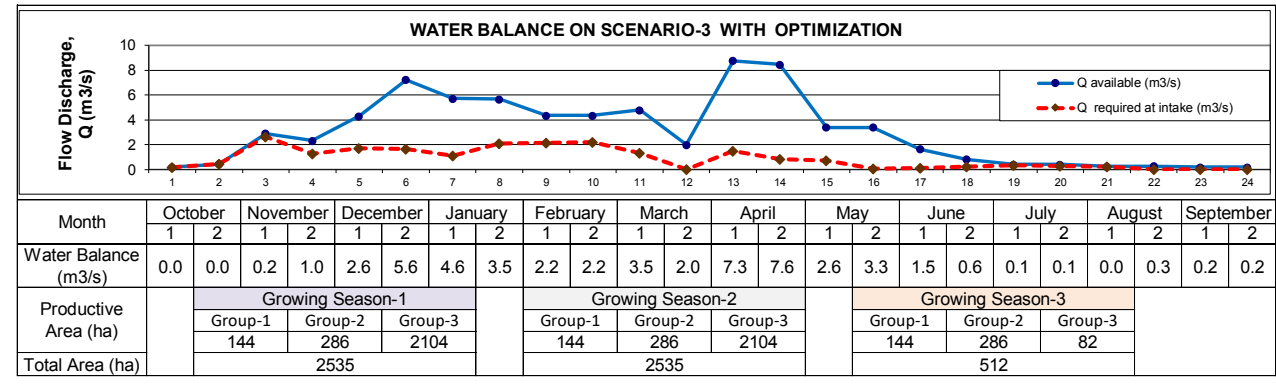

Source: Optimization result

Fig. 5. Water Balance on Scenario 3 with Optimization

\subsection{SRI method as an alternative solution}

This study showed clearly that applying the SRI method in irrigation practice resulted more benefits for farmers than that obtained from conventional method. In the wide scale development of SRI method, however, remains some obstacles that must be solved, such as the availability of organic fertilizers and compost. If SRI method will be applied into alternative farming activities on a large scale, then the supply of manure, compost and other organic fertilizer making materials should be done in an integrated manner.

\section{Conclusion}

The following conclusions can be drawn:

1. The optimization method above can increase the benefit of agricultural products by maximizing area of irrigation field that can be fulfil its water demand, based on water availability and scenario of planting pattern.

2. The best planting method is SRI (System of Rice Intensification), with three groups of water division and three growing season (GS) that begin at early October.

3. The difference in the number of profits between scenario-1 (conventional planting methods) is only 58 billion rupiahs compared to scenario-2 and scenario-3 (SRI planting method) which is 86 billion and 89 billion rupiahs due to the different planting methods used. Scenario-3 is higher in value compared to scenario 2 because the water supply problem in growing season GS-3.

\section{References}

1. Bazaraa, M.S., J.J. Jarvis and H.D. Sherali, Linear Programming and Network flows, John Willey \& Sons Co., (1990)

2. Kuswara, Basic Ideas and Practice of System of Rice Intensification (SRI) Method Ecological Farming, FIELD Foundation Indonesia, (2003)

3. Mays, Larry W., Yeoh Koung Tung, Hydro-systems Engineering and Management, McGraw-Hill Book Company, (1992)

4. Purwasasmita, M., and A. Sutaryat, Paddy SRI organic Indonesia, Penebar Swadaya publisher, (2014)

5. Team of Irrigation Agency, Water-saving in paddy cultivation with System of Rice Intensification (SRI) method, Research Series on Irrigation, the Research and Development Agency of the Ministry of Public Works, (2006) 